BOJAN M. TOMIĆ, istraživač-pripravnik Institut za multidisciplinarna istraživanja Beograd, Kneza Višeslava 1

\title{
PROBLEMI ISTORIJE HOLOGRAFIJE: PREDISTORIJSKI, METODOLOŠKI I DRUŠTVENI*
}

\begin{abstract}
APSTRAKT: $U$ radu je istorija holografije obradena na heuristički način. Takođe, kroz primere je problematizovana i metodologija istorijskog istraživanja. Akcenat je na epistemološkim i istorijskim aspektima otkrića, kao i na načinu na koji se može do njega doći. Istorija holografije predstavljena je dvodelno. Prvi deo izlaže problem predistorije, koji je i najzastupljeniji u radu. Pri tom, navedeni su mogući obrasci predistorije. Drugi deo je prikaz istorije razvoja holografije, sa naglaskom na rani period (1947-1971), u okviru kojeg je dat osvrt na rad istaknutog predstavnika Denisa Gabora. Izlaganje je dopunjeno primenom, a pružen je i osnovni pregled uticaja holografije na umetnost.
\end{abstract}

Ključne reči: holografija, predistorija holografije, otkriće, Denis Gabor, svetlost

Istorija holografije baštini svoje specifičnosti. Traje svega 60 godina, savremena je i aktuelna u ovom času. Stiče se utisak da smo u poziciji da je već doživljavamo kao dovoljno blisku, faktički samorazumljivu. Grešimo li u ovakvoj utvrđenosti? Da li smo spremni da analiziramo holografiju? Jesmo li u prilici da ocenimo njene mogućnosti i naziremo li njene potencijale? Koliko će trajati njena eksploatacija i kada će dostići vrhunac? Kakvi zaključci se mogu izvesti sa pozicije posmatrača dosadašnjeg razvoja? Ova pitanja se odnose kako na budućnost tako i na ocenu trenutnog razumevanja. Pitanja koja se odnose na prošlost i probleme koji su za nju vezani razmatraćemo u predstojećim odeljcima počev od povezanosti holografije sa društvenim naukama i značaja za njih, preko predistorije i istorije, do primena u umetnosti.

${ }^{*}$ Rad je deo projekta Teorija i praksa nauke u društvu: multidisciplinarne, obrazovne i međugeneracijske perspektive (179048), koji finansirana Ministarstvo prosvete, nauke i tehnološkog razvoja Republike Srbije. 
Šezdeset godina trajanja holografije započinje na kraju 40-ih godina prošlog veka i nadovezuje se na decenije koje tome slede. Ono što možemo primetiti - istorija holografije nosi odlike druge polovine 20 . veka. Čitava posleratna dešavanja i specifične okolnosti upleteni su u razvoj ove discipline. Pokušaćemo ukratko da izložimo teme koje su vezane za početak holografije. Istorija vojnog finansiranja i organizacije naučne delatnosti jedna je od njih. Pozicija nauke i tehnologije, u kontekstu posleratne afirmacije novih heroja, i vojna eksploatacija u Hladnom ratu, nude nekoliko početnih pozicija razmatranja. Entuzijazam i uzbuđenje naučnika je posebna tema, za čiju bi obradu vredelo uraditi posebno istraživanje.

Postoji još sličnih ili eksplicitnijih primera u bliskim naučnim oblastima: istoriju lasera i istoriju satelitskog nadgledanja takođe prožima špijunaža i zadužuju vojni sponzori.

\section{Metodologija otkrića}

Ispitujući razvoj holografije možemo se zapitati da li je naznačeni razvoj jedini put koji fiksira istoriju holografije. Ako tvrdimo da je postojao jedan jedini način da se holografija otkrije i da je on pod određenim istorijskim okolnostima ostvaren, ispostaviće se da nismo u pravu. Postoji mnoštvo načina na koje je holografija mogla biti otkrivena.

Jedan od pionira moderne holografije, Amerikanac Emet Lejt (Emmett N. Leith), pozabavio se ovim problemom na sledeći način: posmatrao je holografiju kao odredište, a onda je razmatrao koji su mogući putevi dolaska do rešenja. ${ }^{1}$ Njega je zanimalo kako bi do holografije mogli doći hipotetički pronalazači. Prikazao je 9 opcija od kojih je na tri različita načina holografija zaista i otkrivena (u Velikoj Britaniji, Rusiji i Americi). Preostalih šest mogućnosti su hipotetičke.

\section{Holografija kao tema društvenih nauka}

Postoji na impresivnom meta nivou jedna usaglašenost. Vršnjak holografije je novoprofilisano interesovanje za nauku. Koincidencija koja je zanimljiva za istoričare i za one koji se bave istorijom holografije ogleda se $\mathrm{u}$ tome što istorija, filosofija i sociologija nauke (onakve kakve danas poznajemo) započinju od sredine 20 . veka. Holografija se razvija uporedo sa filosofijom i istorijom nauke. Ovu okolnost vredi proceniti posle 60-godišnjeg zajedničkog razvoja.

${ }^{1}$ Leith, Emmett N., Reflectios on the origin and subsequent course of holography, $\mathrm{u}$ : Proceedings of the SPIE, 5005, 2003, str. 431-438. 
Istorija holografije zaslužuje veću pažnju od strane istraživača iz pomenutih nauka, i to je delom prepoznato. Tokom poslednje dve decenije započeta su istraživanja holografije metodologijom društvenih nauka. Pomenućemo neka od njih.

Pokrenuto je sociološko istraživanje odlika laboratorije kao sveta naučnika koji se bave holografijom. ${ }^{2}$ Izvršena je procena estetskih karakteristika holografije ${ }^{3}$ i značaja holografije kao kulturnog projekta. ${ }^{4}$ Prezentovani su aspekti holografije $u$ odnosu na arhitekturu, ${ }^{5}$ zatim odnos posmatrača (ali i javnosti) prema hologramu, ${ }^{6}$ te koncept saradnje umetnika i naučnika. ${ }^{7}$ Vrednost takvih istraživanja je prepoznata i kao korisna za izradu doktorskih disertacija umetnika. ${ }^{8}$

Istorija holografije nije kao istorija drugih naučnih disciplina, instrumentalnih tehnika i dostignuća. Ona je specifična i prožeta motivima - sociološkim, vojnim, političkim, ${ }^{9}$ ekonomskim, trgovinskim, heurističkim, kulturološkim, umetničkim, pa i oblicima popularne kulture - koji su, zajedno sa naučnim i tehničkim aspektima, uticali na njen razvoj. Interesantno je i pitanje koliko na percepciju i razvoj, time i na celokupnu novu nauku, utiču kulturni obrasci.

Značaj holografije kao savremenog fenomena od interesa za istraživače društvenih nauka ogleda se u naznakama koje smo dali. One (društvene nauke) su, pak, kroz efekat povratne sprege važne za kritičko vrednovanje, ali i formiranje perspektiva naučnih oblasti. Centralno mesto istorije kao nauke $\mathrm{u}$ tome je nedvosmisleno.

${ }^{2}$ Tchalakov, Ivan, Making a Hologram: A book about Light, about Scientists and their world, Sofia 1998; Tchalakov, Ivan, The Object and the Other in Holographic Research: Approaching Passivity and Responsibility of Human ActorsScience, u: Technology \& Human Values, 29, 2004, str. 64-87.

${ }^{3}$ Maline, Sarah, Aesthetic problem of figural holography, u: Proceedings of the SPIE, 1732, 1993, str. 438-443.

${ }^{4}$ Maline, Sarah, The Imaginary Hologram: A Short Cultural History, 2009, u: ISDH International Symposium on Display Holography, http://www.isdh. org. cn/en/final-program-content. asp? ID=50, (01.07.2011).

${ }^{5}$ Pepper, Andrew, Architectural Holography: Building with light, decorating with space, 2002, u: Andrew Pepper - Writing, http://www.apepper. com/content/articles/rca2002/index. html, (1. 7. 2011).

${ }^{6}$ Pepper, Andrew, Holography, Visual Medium or Cheap Trick?, u: Art Monthly, 122, December/January 1988/89, 9-13.

${ }^{7}$ Pepper, Andrew, The art of collaboration: A conflict of disciplines or constructive relationship, u: Proceedings of the SPIE, 2333, 1994, str. 247-254.

${ }^{8}$ Gamble, Susan, The hologram and its antecedents, 1891-1965: the illusory history of a three-dimensional illusion, äîêôî̃nêà òåçà, University of Cambridge 2003.

${ }^{9}$ Johnston, Sean F., Der parallaktische blick: der militärische ursprung der holographie, u: Das Holografische Wissen, urednici Rieger, Stefan i Schroter, Jens, Zurich 2009, 33-57. 


\section{Ko će pisati istoriju?}

Interesuje nas da li ishođenje (obrazovanje, formiranje) iz određene discipline, utiče na različite načine pristupa istoriji holografije. Pitanje je kako bi zasnivanje jedne takve oblasti opisali inženjeri, umetnici i naučnici, odnosno da li bi se potencijalna razlika ispoljila jedino u korišćenju alternativnog izraza za razmatranu oblast. Izvesno je da ne bi.

Naučni pristup, kada je ispoljen ultimativno, zahteva potragu koja se ne okončava. Zbog toga moramo ostaviti otvorenim pitanje: šta i kako prozboriti o odnosu istorije kao nauke prema onim naučnicima čiji su papiri, radovi, proračuni i predlozi ostali sabijeni u fiokama. Popis tih listova se ne nalazi u udžbenicima.

Sve ovo implicira našu odgovornost. Nije nam cilj da u ovom radu sledimo ili kreiramo uprošćavanja da bi se dobila poučna priča. Jedan od zadataka modernih istorijskih istraživanja jeste svesno izbegavanje da se učestvuje u stvaranju istorijskog mita.

\section{Filološka analiza kao potencijalna temporalna odrednica}

Prilikom određivanja trenutka kada zaista kreće istorija jedne oblasti javljaju se poteškoće. Prema nekima, on se poistovećuje sa časom kada se ustanovi termin koji naznačava oblast. U tom slučaju se treba zapitati kada se počelo govoriti holografija. Ispostavlja se da to ne bi bio pravi kriterijum. Izraz holografija nije bio jedini. Paralelno je postojalo više termina koji su označavali novu oblast - holoskopija, rekonstrukcija talasnog fronta, interferenciona mikroskopija, difrakciona mikroskopija, fizička senka, difrakciona slika, Frenelov difrakcioni model (obrazac), čak i gaboroskopija. $^{10}$

\section{Karakterizacija predmeta}

Terminologija predstavlja pomoć istoričarima u identifikaciji nosilaca paradigme. No, potrebno je insistirati na zahtevu da istraživanje bude što obuhvatnije.

Da bismo okarakterisali sam predmet istorijskog proučavanja, neophodno je definisati skup smernica, elemente tumačenja, metod. Fizička optika sa naznačenjem na koherenciji, interferenciji, fokusiranju, defokusiranju, realnim i virtuelnim slikama, obezbeđuje metaforu za sam pred-

${ }^{10}$ Nabrajanje preuzeto iz Johnston, Sean F., Holographic visions: A History of New Science, New York 2006, 16. 
met. ${ }^{11}$ Njega je, možemo primetiti, moguće sagledati u celosti tek kada u razmatranje uključimo sve elemente koji čine opis dešavanja, događaja, odnosno koji čine samu istoriju discipline. Time se slika obrazuje ne samo od uspešnih realizacija, „pravih odluka“ i nagrada, već i od različitih poriva, zabluda, ideala, nesvakidašnje posvećenosti, razočarenja.

Još jedno zapažanje možemo dodati kao prilog kritičkoj karakterizaciji predmeta. Kada se trudimo da istorijski obradimo jednu temu, krećemo od onoga što nazivamo ili tumačimo kao početak neke oblasti, međutim početak istorije holografije može da se posmatra i kao završetak jednog procesa istraživanja, kao ispunjenje jedne teme, u ovom slučaju jednog segmenta fizike - optike.

\section{PREDISTORIJA}

I sama predistorija može se problematizovati. Naročito zbog okolnosti da je tematika kojom se bavimo savremena. Nesumnjivo, imamo nešto što je novo i nadahnjujuće - ali da li ga možemo uokviriti u 60 godina i kao istoričari klasifikovati tome prethodujuće angažovanje kao nevažno za predmet i ne obazirati se na ideje, pronalaske, hipoteze koje su prethodile 40-im godinama prošloga veka?

Ako odlučimo da ne postupimo na predloženi način, naići ćemo na određene poteškoće. Problem predistorije neće biti izbrisan ni u tom slučaju. Zainteresujemo li se, pak, za prošlost, ostaje nam dilema koliko daleko da odemo u proučavanju. Da li je za opis predistorije i za pobrojavanje neophodnih preduslova dovoljno u razmatranju zahvatiti 50 godina, 100, 200 ili 400 godina? Gde i na koji način napraviti rez? Nekoliko bazičnih ideja je u danima koji prethode prvim radovima o holografiji bilo neophodan preduslov za njeno razvijanje. Ali nedoumica je da li u pristupu koji preovlađuje u studiji ići i dotle da se spomene tamna komora (camera obscura) i Kanaleto, italijanski barokni slikar iz 16 . veka.

\section{POKUŠAJI PISANJA PREDISTORIJE}

Holografija, kao oblast i kao tehnika, počiva na jednoj osobini koja se proučava $u$ talasnoj optici - svetlost se ponaša kao talas. Ona se može $u$ obliku svetlih i tamnih linija zapisati na filmu. Linije su, relativno rečeno, gusto raspoređene i nose kompletnu informaciju o izgledu objekta. Kada taj film osvetlimo svetlošću, rekonstruiše se trodimenzionalna slika. To je hologram. Posmatrač je ubeđen da se iza holograma nalazi predmet u svojoj punoj trećoj dimenziji.

\footnotetext{
${ }^{11}$ Johnston, Sean F., Holographic visions..., 10.
} 
Snimanje trodimenzionalnih objekata na jednu ravan je zadivljujuća ideja, i revolucionarna misao. Holografski metod stvaranja i reprodukovanja trodimenzionalnih slika na fotografskoj ploči primenom koherentne svetlosti $^{12}$ (u početku živine lampe, kasnije lasera) biće primer koji ćemo istorijski pokušati da rasvetlimo. Tragajući za njim ispitaćemo istoriju osobina svetlosti, mikroskopije, fotografije, lasera...

Razmotrimo moguće verzije predistorije našeg predmeta.

Prva verzija

Predistorija traje 350 godina. U izboru četiri veka doprinosa, ovako bi izgledala aktivnost naučnika:

- Snelov zakon prelamanja svetlosti, oko 1621, nazvan po matematičaru, fizičaru i astronomu iz Lajdena (Willebrord Snel van Roijen, 1580-1626);

- Difrakcija - objašnjena u Grimaldijevoj knjizi posmrtno objavljenoj 1665. godine (Francesco Grimaldi, 1618-1663, jezuita, bolonjski profesor);

- Naznake za talasni model svetlosti daje Robert Huk (Robert Hooke, 1635-7003), engleski filosof, pronalazač i arhitekta u knjizi Mikrografija, 1667;

- Hajgensov princip (Christiaan Huygens, 1629-1695, holandski naučnik) - nalazi se u knjizi Rasprava o svetlosti pisanoj 1673-1678, objavljenoj tek 1690;

- Njutnova Optika (1704), Njutnova aktivnost na prizmi.

Druga verzija

Postoje i razmatranja ${ }^{13}$ koja istoriju holografije procenjuju na 200 godina.

Treća verzija

Predistorija traje 150 godina. Navešćemo eksperiment koji je povod za takvo razmišljanje.

Na početku 19. veka, tačnije 1801. godine, odigrava se naizgled trivijalna i beznačajna akcija - puštanje zraka svetlosti u mračnu sobu kroz dva otvora. No, ovakvo „igranje“ obeležiće jedan interesantan rezultat za nekoliko narednih vekova. On će se naknadno pokazati još interesantniji

${ }^{12}$ Koherentna svetlost je sastavljena od talasa koji imaju određene sličnosti (jednake frekvencije i istovremeno postizanje maksimuma i minimuma - drugačije rečeno „u fazi“ su). Sunčeva svetlost i svetlost obične sijalice nisu koherentne. Najbolji izvor koherentne svetlosti je laser, a pre njegovog pronalaska koristio se prirodni izvor koherentne svetlosti živina lampa. str. 9-12.

${ }^{13}$ Kirkpatrick, Paul, History of holography, u: Proceedings of the SPIE, 15, 1968, 
kako se bude smanjivala količina svetlosti koju eksperimentator pušta kroz otvore. U toj seriji eksperimenata engleski naučnik Tomas Jang pratiće nastajanje pravilno raspoređenih tamnih i svetlih linija na zastoru. ${ }^{14} \mathrm{Na}$ mestu gde se očekivalo da će biti svetlo pojavile su se tamne linije. Pojava je nazvana interferencija. Ona je posledica sabiranja (superpozicije) svetlosnih talasa koji se istovremeno prostiru u prostoru. Na mestima na kojima se susreću maksimumi dve talasne funkcije koje potiču od dva koherentna izvora zračenja (svetlosnih talasa) dolazi do pojačanja intenziteta svetlosti pojavljuje se svetla linija. Na mestima na kojima jedna talasna funkcija ima maksimum a druga minimum funkcije se „potiru“, pa je intenzitet svetlosti nula - pojavljuje se tamna linija. Niz svetlih i tamnih linija predstavlja interferencionu sliku.

\section{Četvrta verzija}

Predistorija traje 50 godina. Nekome bi za formiranje stanovišta o predistoriji dovoljno bilo da pregleda dva rada iz 19. veka, čiji je autor francuski Nobelovac Gabrijel Lipman (1845-1921). To su:

Lippmann, G., La photographie des couleurs, u: Comptes Rendues des Scéances de l'Académie des Sciences, 112, 1891, str. 274-275.

Lippmann, G., Sur la théorie de la photographie des couleurs simples et composées par la méthode intérférentielle, u: J. de Physique, 3, 1894, str. 97-107.

\section{Peta verzija}

Ako bi se predistorija pratila po dodeljenim Nobelovim nagradama, ovako bi izgledala:

Nobelova nagrada 1908. godine - Gabrijel Lipman - interferenciona kolor fotografija;

Nobelova nagrada 1915. godine - Vilijam Brag (William Bragg) difrakcija rentgenskog zračenja, $x$-zračni mikroskop;

Nobelova nagrada 1953. godine - Fric Cernike (Frits Zernike) fazno kontrastna mikroskopija.

\section{SAMA ISTORIJA}

Na početku konkretnog istorijskog razmatranja prisutna je dilema da li pratiti istoriju predmeta do današnjih dana. U novije vreme holografija doživljava ekspanziju, što je odlika trenutnog stanja, koje se još uvek ne može nazvati istorijom. Diskretno ćemo pokušati da nađemo granicu sa istorijom.

${ }^{14}$ Young, Thomas, Experiments and Calculations Relative to Physical Optics, u: Philosophical Transactions, of the Royal Society of London, 94, 1, 1804, str. 1-16. 
Period 1947-1971. je istorijski najinteresantniji i najzahvalniji za opisivanje. Tokom tih godina odigravala se uzbudljiva saga, postavljale su se osnove teme. Traganje se odvijalo u nepoznatom. Nizali su se uspesi i otkucana je verifikacija. Na kraju je stigla i nagrada. Za to isto vreme uočavaju se takođe: tumaranje, podsmesi, okrenuta leđa, potištenost...

Pre nego što krenemo sa analizom tog perioda dodaćemo nekoliko smernica za istraživanje. Moguće je napraviti posebna sociološka i psihološka istraživanja o radu u okolnostima izolovanih laboratorija i stroge kontrole rezultata daleko od očiju javnosti, te paranoidnosti i frustriranosti ljudi koji su učestvovali u eksperimentima na samom početku. ${ }^{15}$

\section{POČECI \\ Novi mikroskopisti}

Kao model za početak priče o holografiji uzima se 1947. godina i jedan čovek. Prati se šta on sve čini tih dana. Ime istaknutog predstavnika je Denis Gabor (1900-1979).$^{16}$ Kao mnoge epizode u istoriji nauke i Gaborov rad izgleda manje uređen i odlučan pri detaljnijem ispitivanju. ${ }^{17}$

On je zainteresovan za tada novo polje u fizici - elektronsku mikroskopiju. Njegov doktorat o oscilografu katodnih zraka sa sistemom magnetnih sočiva, bio je potpora nastanku prvog elektronskog mikroskopa. Njega su u Nemačkoj 30-ih godina prošlog veka realizovali Ernst Ruska i Maks Knol (Ernst Ruska, Max Knoll). U društvu tradicionalnih optičkih mikroskopista pojavljuju se novi - elektronski mikroskopisti. Gabor se bavio i istraživanjima vezanim za infracrvenu svetlost, odnosno konkretnije detekciju letilice uz pomoć toplote emitovane od strane njenog motora. ${ }^{18}$

\section{Počeci holografije}

Gabor je 1947. godine zaposlen u laboratoriji u Ragbiju, Engleska (Research Laboratory of the British Thompson-Houston Company). Tokom rada na elektronskom mikroskopu suočen je sa ograničenjima: elektroni, koji se ponašaju i kao čestice i kao talasi, imaju talasnu dužinu ${ }^{19}$ (De Brolje-

${ }^{15}$ Wang, Jessica, American Science in an Age of Anxiety: Scientists, Anticommunism, and the Cold War, Chapel Hill i London 1999, 254-262.

${ }^{16}$ Originalno akcentovano na mađarskom ime se piše Dénes Gábor.

17 Johnston, Sean F., Holographic visions..., 16.

${ }^{18}$ Allibone, Thomas. E., Dennis Gabor: A biographical memorial lecture, u: Holosphere, 10, 1, 1981, str. 4-6.

${ }^{19}$ Talasna dužina je rastojanje između dve susedne tačke na talasnoj funkciji koje su u istoj fazi oscilovanja. Slikovito, možemo je zamisliti kao rastojanje između dva susedna maksimuma talasne funkcije. 
va talasna dužina) koja nije mogla biti podržana tadašnjim optičkim sistemima unutar elektronskog mikroskopa. Upravo bavljenje tim problemima pretpostavka je holografije. Njegova okupiranost bila je elektronska holografija. Na Vaskrs 1947. godine, dok je čekao da uđe na teniski meč, došao je do rešenja koje će obeležiti njegov rad u nauci. ${ }^{20}$

Ono što je bilo interesantno Gaboru, a što i danas fascinira u priči o holografiji, vredelo bi objasniti u kratkom.

Sama fotografija je dvodimenzionalna slika. Ona ne sadrži celokupnu informaciju o predmetu. Fotografija beleži samo intenzitet i (ako je u boji) talasnu dužinu svetlosti koja dolazi sa lika. Faza svetlosnog talasa je izgubljena. Hteli bismo više od toga, težimo celovitosti vizuelnog doživljaja. Holografija nam to (donekle) nudi. Na njoj je osim intenziteta, zabeležena i faza svetlosnog talasa, te ona, u stvari, čini potpunu rekonstrukciju izgleda objekta. Holografija se zasniva na interferenciji. Slaganje (interferencija) se obavlja između referentnog talasa (koherentne pozadine, snopa) i talasa odbijenog sa snimka ili lika. Hologram se rekonstruiše uz pomoć svetlosti u optičkom sistemu koji otklanja odstupanja (aberaciju) elektronske optike.

U holografiji je upotrebljena ideja da se pravljenje slike objekta obavi $u$ dve faze - u prvoj fazi vrši se snimanje, a u drugoj rekonstrukcija slike. Takvu ideju je krajem 19. veka razvio nemački fizičar Ernst Abe (Ernst Abbe), jedan od osnivača moderne optike. Dvadesetih i tridesetih godina 20. veka Mičeslav Volfke (Mieczysław Wolfke) i ser Vilijam Lorens Brag (Sir William Lawrence Bragg) razmatrali su tehniku u kojoj se u prvoj fazi koristi rendgensko zračenje, a u drugoj vidljiva svetlost. Gabor je u holografiji snimanje obavljao uz pomoć elektronskih talasa, a rekonstrukciju svetlosnim talasima. Pomoću elektronskog mikroskopa je $u$ prvoj fazi pravio neku vrstu senke objekta sastavljenu od svetlih i tamnih oblasti (interferenciona slika) i snimao je na fotografski film. Takva slika sadrži sve informacije koje su potrebne da bi se rekonstruisao objekat. U drugoj fazi film je $u$ posebnoj optičkoj aparaturi osvetljavao vidljivom svetlošću čime je rekonstruisan talasni front jednak prvobitnom. Taj talasni front daje sliku originalnog lika.

Da interferencioni lik dobijen $u$ eksperimentima sadrži celovitu informaciju, Gabor je naznačio dodelivši mu naziv prema grčkim rečima holos (öגos) - ceo i grafe ( $\gamma \rho \alpha \varphi \eta ́)$ - pisanje.

Ako bi bibliografski trebalo da predstavimo četiri godine Gaborovog delanja na ovom polju, učinili bismo to nabrajajući tri značajna rada iz perioda 1947-1951. godine. Oni predstavljaju kratku istoriju: Gabor, Dennis, A New Microscopic Principles, u: Nature, 161, 1948, str. 777-778; Gabor, Den-

${ }^{20}$ Gabor, Dennis, Holography, 1948-1971, u: Nobel Lectures in Physics 1971-1980, urednik Lundqvist, Stig, Singapore 1992, 13. 
nis, Microscopy by Reconstructed Wavefronts, u: Proc. Roy. Soc, A 197, 1949, str. 454-487; Gabor, Dennis, Microscopy by Reconstructed Wavefronts: II, u: Proc. Phys. Soc, 64, 1951, str. 449-469.

Kao sam početak holografije u literaturi se pominje publikovanje prvog navedenog rada - Novi principi mikroskopije, godine 1948.

Već smo pokazali ko je Gabora inspirisao, koga je doživljavao kao preteče. Bio je „na leđima dva velika fizičara“ - nobelovaca Vilijama Braga i Frica Cernikea. Brag je pokazao Gaboru rentgensku mikroskopiju i uputio ga u optičke Furijeove transformacije. Ni Gabor ni Brag nisu znali da je Mičislav Volfke ${ }^{21}$ predložio ovaj metod 1920. godine, ne realizujući ga eksperimentalno.

Godine 1950. pokrenut je program holografskog elektronskog mikroskopa u laboratoriji u Aldermastonu (Research Laboratory of the Associated Electrical Industries) pod rukovodstvom engleskog fizičara Tomasa Alibona (T. E. Allibone). Uz Alibona i Gabora kao kolege i saradnici bila su još trojica naučnika (M. W. Haine, J. Dyson i T. Mulvey). Gabor je potom prešao u Impirijal Kolidž (Imperial College), gde je radio kao konsultant. Tokom trogodišnjeg rada uspeli su da značajno usavrše elektronski mikroskop, ali su na kraju odustali, ne nalazeći u to vreme mogućnost uspešne realizacije.

To i ne čudi, znajući koliko je tada postojalo smetnji na elektronskom mikroskopu. Sliku su kvarile vibracije, zalutalo magnetno polje, pomeranje nosača, kontaminacija objekta. Još veći problem je predstavljalo to što se sve pogoršavalo korišćenjem duge ekspozicije, koju su eksperimenti zahtevali. Elektronsku mikroskopiju tada su limitirala i velika odstupanja optičkog sistema (optičke aberacije). Tek 20 godina kasnije, stvoreni su povoljni uslovi za realizaciju onoga što su Gabor i kolege započeli.

Posle prvih Gaborovih radova na temu rekonstrukcije talasnog fronta, reakcija je brzo usledila. Mali pomak učinio je Britanac Rodžers (G. L. Rogers), koji je ostvario poboljšanje u tehnici postigavši prvi fazni hologram, pri tom i rasvetlivši teoriju.

U Kaliforniji su naučnici (A. Baez, H. El-Sum i P. Kirckpatrick) načinili napredak u rentgentskoj holografiji. Što se Gabora tiče, on je sa svojim pomoćnikom Grosom (W. P. Gross) konstruisao holografski interferencioni mikroskop, u kojem je sekundarni lik objekta, koji je do tada pravio smetnje u polju mikroskopa, anuliran. Optička industrija nije reagovala na ovo, što je uslovilo da je Gabor objavio svoj rad tek posle 11 godina, 1966. Period od 1955. on ocenjuje kao stanje hibernacije za holografiju. Kasnih 50-ih Gaborov rad je okarakterisan od strane nekolicine stručnjaka

${ }^{21}$ Wolfke, Mieczysław, Über the Möglichkeit der optischen Abbildung von Molekulargittern, u: Physikische Zeitschrft, 21, 1920, str. 495-497. 
kao „beli slon“. ${ }^{22}$ Što bi značilo da utrošeni novac za puko održavanje nadmašuje bilo kakvu vrednost buduće primene, a ni u sadašnjosti ne donosi koristi.

Tih godina, podstaknut zabrinutošću za budućnost društva zbog ubrzanog tehnološkog razvoja, Gabor se posvećuje razmišljanjima vezanim za interakciju nauke i društva. Objavio je dve knjige - Inventing the Future (1963) i The Mature Society (1972) $)^{23}$ - u kojima i sam daje doprinos sociologiji i filosofiji nauke.

Sada ćemo pažnju usmeriti na državu koja se ubrzano razvijala u naučnu i tehnološku silu - Sovjetski Savez.

U Sovjetskom Savezu postojala je strategija značajnog ulaganja $u$ nauku. Naučnici i „tehnička lica“ su tamo predstavljali novu privilegovanu elitu. ${ }^{24}$ Godine 1954. na Državni optički institut Vavilov (GOI) ${ }^{25} \mathrm{u}$ Sankt Peterburgu (tada Lenjingrad) dolazi još jedan budući pionir holografije, mladi istraživač Juri Nikolaevič Denisjuk (Юriй Nikolaevič Denisюk). Za razliku od Gabora, njegovo istraživanje se nije odvijalo unutar istraživačke grupe koju je činio veliki broj ljudi, već je donekle bilo usamljenički poduhvat. Denisjuk je inspiraciju pronašao u delima ruskog pisca naučne fantastike Ivana Antonoviča Jefremova (Iván Antónovič (Antúpovič) Efrémov). Želja mu je bila da uz pomoć optičkih uređaja napravi trodimenzionalnu sliku, identičnu trodimenzionalnoj slici iz Jefremovljeve priče Zvezdani brodovi. ${ }^{26}$ Vršio je istraživanja da bi razvio takve uređaje za prikaz slike koji bi omogućili apsolutnu iluziju prisustva prikazanog objekta. ${ }^{27}$ Otkrio je da je neke od problema koji ga interesuju ranije razmatrao Lipman predloživši metodu fotografije $u$ boji 1908. godine. ${ }^{28}$ Za njegov projekat je od krucijalnog značaja bila fotohemijska ekspertiza na Institutu Vavilov.

Godine 1962. Denisjuk je objavio $\operatorname{rad}^{29}$ u kome kombinuje holografiju sa izvrsnom Lipmanovom metodom fotografije $u$ boji za koju je Francuz dobio Nobelovu nagradu. Iz te metode je proistekao hologram koji se može videti pod svetlošću obične sijalice (belom svetlošću), za razliku od

${ }^{22}$ Johnston, Sean F., Holographic visions..., 16.

${ }^{23}$ Gabor, Dennis, Inventing the Future, London 1963; Gabor, Dennis, The Mature Society, London 1972.

${ }^{24}$ Medvedev, Zhores A., Soviet Science, Oxford 1979.

${ }^{25}$ Do kraja sedamdesetih godina Vavilov institut (GOI) je imao čak 12.000 zaposlenih i bio najveća optička institucija u svetu.

${ }^{26}$ Zvëzdnble korabli

${ }^{27}$ Denisyuk, Yuri N., Fundamentals of Holography, Moscow 1984, 64.

${ }^{28}$ Connes, Pierre, Silver salts and standing waves: the history of interference colour photography, u: Journal of Optics, 18, 1987, str. 147-66.

${ }^{29}$ Denisyuk, Yuri N., Photographic Reconstruction of the Optical Properties of an $\mathrm{Ob}$ ject in its Own Scattered Radiation, u: Doklady Akademii Nauk SSSR, 144, 1962, str. 12751278. 
holograma koje su razvijali naučnici u Mičigenu, a koji je mogao da bude vidljiv samo pod laserskom svetlošću. I pored svih ovih činjenica, Juri Denisjuk nije mnogo pominjan u zapadnim izvorima sve do 1970. godine.

\section{NOVINE U HOLOGRAFIJI I PRIMENE}

Do sada smo predstavili okvir koji se sastoji od relevantnih metodologija i koncepata istraživanja. Hronologija događaja je neodvojiva od toga i prezentovaćemo je na način primeren istorijskom izlaganju, uzimajući u obzir zahtevnost teme. Pazeći da obilnost informacija ne učini tekst nepreglednim, činjenice i događaje ćemo predstaviti ukratko.

\section{Prvi laserski hologram}

Svetlost holograma ulazi konačno $\mathrm{u}$ istoriju 1963. Te godine napravljen je prvi uspešan laserski hologram. To su učinili pomenut Emet Lejt i njegov kolega Juris Upatniks (Juris Upatnieks), sa Univerziteta u Mičigenu (University of Michigan, Ann Arbor). Time je počela era moderne holografije.

Teorijsku pripremu Lejt je započeo 1955. godine. Ovo je bilo nepoznato Gaboru i ostalima, jer je Lejt sa saradnicima (Cutrona, Porcello i Vivian) svoje prve ideje dobio radeći na programu vezanom za vojni radar na Institutu za nauku i tehnologiju Mičigenskog univerziteta u Vilou Ranu, An Arbor (University of Michigan's Institute of Science and Technology at Willow Run). To je bio radar koji je doprinosio uočavanju objekata bočno od letilice („side-looking radar“), objašnjen u radu Lejtovih saradnika ${ }^{30}, u$ čijoj je osnovi bilo nešto slično elektronskoj holografiji (zapravo radilo se o dvodimenzionalnoj holografiji sa EM talasima).

Laser je postao dostupan od 1962. godine i omogućio je lak i efektivan metod za eliminaciju još jednog problema u optici - sekundarne slike. Naziv tog metoda je „skew reference wave“. ${ }^{31}$ Helijum neonski laser nadmašivao je živinu lampu (koja je do tada korišćena kao najbolji izvor koherentne svetlosti) 3000 puta. Lejt i Upatniks su u Žurnalu Optičkog društva Amerike (Journal of the Optical Society of America), u novembru 1964,

${ }^{30}$ Cutrona, L. J., Leith, E. N., Porcello, L. J. i Vivian, W. E., On the Application of Coherent Optical Processing Techniques to Synthetic Aperture Radar, u: Proceedings of the IEEE, 54, 1966, str. 1026-1032.

${ }^{31}$ Leith, E. N. i Upatnieks, J., Wavefront Reconstruction with Continuous-Tone Objects, u: Journal of the Optical Society of America, 53, 1963, str. 1377-1381; Leith, E. N. i Upatnieks, J., Wavefront Reconstruction with Diffused Illumination and Three-Dimensional Objects, u: Journal of the Optical Society of America, 54, 1964, str. 1295-1301. 
pokazali dve slike rekonstruisane sa jednog holograma. To je bio prvi dokaz o mogućnostima korišćenja holograma za skladištenje informacija i slike.

\section{Skladištenje informacija}

Lejt je mogao da uskladišti 12 različitih slika na jednoj emulziji, a 1971. godine bilo je moguće smestiti 100-300 slika. Skladištenje informacija je važno pitanje i značajan primer primene holograma. Holografskim pohranjivanjem podataka bavio se 60 -ih godina i Anderson, ${ }^{32}$ naglašavajući da je sve to samo skroman početak. Herden je 1963. objavio rad $^{33} \mathrm{u}$ kojem saopštava da se može uskladištiti jedan bit informacija na aproksimativno jednoj talasnoj dužini na kub (treći stepen). Nije pitanje koliko je to tada bilo praktično i koliko izvodljivo, već ovaj pristup govori o teorijskim mogućnostima.

\section{Novi momenti}

Posle toga počinje ubrzan razvoj. Holografija je od početka, naravno, bila trodimenzionalna, ali kod prvih malih holograma, zbog nerazvijene tehnologije, treću dimenziju je jedino bilo moguće zapaziti fokusiranjem kroz polje mikroskopa. Počelo se zapažati kakve novine donosi holografija. Pojava "difuznog" holograma bila je ocenjena kao šok. On je nastupio u času kada je postalo jasno šta je jedna od najzanimljivijih odlika holograma. Iz malog fragmenta slike se može rekonstruisati izgled čitavog objekta. Kada se hologram iseče na dva dela, na svakoj polovini se opet vidi ceo objekat. Manji deo (i to bilo koji) dovoljno je velik da postane difrakcioni obrazac, jer sadrži informaciju o celom objektu. Jedina razlika je što manji deo sadrži više šuma, odnosno gube se detalji u odnosu na celinu zabeležene slike. Difuzni hologram je tako shvaćen kao raspoređena memorija. Ovo je pobuđivalo primene, nove ideje i kreativna povezivanja. Američki naučnik i inženjer Klod Šenon (Claude E. Shannon) povezuje holografiju sa teorijom informacija, čiji je utemeljivač. Uzbuđenje je bilo veliko - izgledalo je kao da se informacija vadi iz haosa.

Stari problemi su laserom bili „izbrisani“. Od 1965. godine pa nadalje velika stabilnost aparature nije izričito potrebna, iz razloga što se hologrami snimaju u delu mikrosekunde, pulsnim laserom.

32 Anderson, L. K., Holographic Optical Memory for Bulk Data Storage, u: Bell Lab Reports, 46, 1968, str. 318.

${ }^{33}$ Van Heerden, P. J., A New Method of Storing and Retrieving Information, u: Applied Optics, 2, 1963, str. 387-392. 


\section{Holografija u umetnosti i nova otkrića}

Buran razvoj je doveo do zanimljivih ideja i primena. Krajem šezdesetih godina, Noks i Bruks ${ }^{34}$ ostvarili su kinematografsko snimanje holografskog filma, gde su zabeležili let komarca. Let je snimljen sa priličnom dubinom, a refokusiranje je ostvareno $u$ svakom frejmu (kadru). ${ }^{35}$ Još jedan uspeh TRW grupe (Ralph Wuerker i saradnika) bila je holografska interferometrija. Ona se koristi pri analizi fluida i ima široku upotrebu u inžinjerstvu.

Dostignuće pulsne holografije 60-ih godina predstavlja holografski trodimenzionalni portret (načinio ga je L. Siebert iz Conductron Corporatio, kasnije pripojeno McDonnel-Douglas Electronics Company, St Charles Missouri). Ostvareno je upotrebom rubidijumskog, impulsnog lasera, koji je realizovan od strane Majmana (T. H. Maiman). Ova kompanija je imala mogućnost velike produkcije, pa je odigrala značajnu ulogu u početku komercijalne proizvodnje holograma.

Pauel i Stetson (R. L. Powell i K. A. Stetson) su 1965. godine došli do interesantnog otkrića - ako se koristi dupla ekspozicija, prva na objektu koji je u stanju mirovanja, a druga na objektu prilikom vibracije, pojavljuju se konture, koje ukazuju na vibracione modove. ${ }^{36}$ Time je omogućeno nedestruktivno testiranje holografskom interferometrijom, kao najznačajniji model industrijske primene holografije (GCO - G. C. Optronics u Ann Arbor, Michigan).

Dvobojni reflektujući hologram, koji se može osvetliti belom svetlošću, prvi put su proizveli 1965. godine Strouk (George W. Stroke) ${ }^{37}$ i saradnici. Jednobojni reflektujući hologram je razvijen do visoke perfekcije novim fotografskim procesom od strane Peningtona. ${ }^{38}$ Prepoznavanje slike je shvaćeno kao važna tema i trasirano u osnovnom radu Vander Lugta. ${ }^{39}$

Na to se nadovezuje i jedna zanimljivost. Možemo uzeti kineski ideogram i od njega dobiti odgovarajuću englesku, srpsku ili rusku rečenicu. Baters (J. N. Butters) i Vol (M. Wall), sa Univerziteta u Lofborou u Velikoj

${ }^{34}$ Knox, C., i Brooks, R. E., Holographic Motion Picture Microscopy, u: Proceedings of the Royal Society of London, 174, 1969, str. 115-121.

${ }^{35}$ Frejm, ili kadar, je pojedinačna slika koja danas čini dvadesetčetvrti, dvadesetpeti ili trideseti deo sekunde na filmu.

${ }^{36}$ Powell, R. L. i Stetson, K. A., Interferometric Vibration Analysis by Wavefront Reconstruction, u: Journal of the Optical Society of America, 55, 1965, str. 1593-1597.

${ }^{37}$ Džordž Strouk vodi poreklo od nemačkih Jevreja, a rođen je 1924. u Jugoslaviji.

38 Pennington, K. S. i Harper, J. S., Techniques for Producing Low-Noise, ImprovedEfficiency Holograms, u: Applied Optics, 9, 1970, str. 1643-1650.

${ }^{39}$ Vander Lugt, A., Signal Detection by Complex Spatial Filtering, u: IEEE Transactions on Information Theory, 10, 1964, str. 139-145. 
Britaniji, bili su prvi koji su napravili hologram koji od portreta proizvodi potpis vlasnika. Hologram može biti prilično univerzalni prevodilac. Do pred kraj 20. veka to je bilo nešto sasvim novo, neobično i unikatno, a danas smo svedoci široke proizvodnje holograma - od primene $u$ nauci i tehnici, do ličnih karata i niskobudžetnih dekorativnih slika. Holografija je pospešila rešavanje mnogih problema $u$ fizici i tehnici. Koristi se za fotografisanje brzih pojava sa velikom prostornom dubinom, za prostorno prikazivanje gasova i tečnosti, deformacija u elastičnim predmetima. Takođe, omogućila je novi princip rada kompjutera na bazi optičkih memorija.

Muzeologija je obogaćena ovim otkrićima. Prva izložba holograma održana je 1968. godine u Mičigenu. Prateći potrebu da se osnuje internacionalni centar za razvoj holografije, 1976. godine u Njujorku je otvoren prvi muzej holografije - New York Museum of Holography $(\mathrm{MoH})$. U njegovoj organizaciji, naredne godine je otvorena putujuća izložba u Torontu koja je trajala deset godina u toku kojih je obišla SAD i inostranstvo. Salvador Dali je, osećajući značaj novine, izlagao svoje holograme, 1972. godine u Njujor$\mathrm{ku}$ (Knoedler Gallery). Posle šesnaest godina muzej u Njujorku je zatvoren, a njegovu funkciju je 1993. delimično preuzeo muzej u Masačusetsu (MIT Museum, Cambridge, MA). Ova institucija danas ima najveću kolekciju holograma. U osamdesetim u devedesetim godinama postojalo je više časopisa koji su se bavili holografijom i kulturom (L. A.S. E.R. News, Wavefront, Creative Holography Index itd.). Njihovu funkciju i obaveštavanje o društvenim događajima vezanim za holografiju danas preuzimaju sajtovi na internetu (Holo World - http://www.holoworld. com; Holophile, Inc. http://www.holophile. com itd).

Iste godine kada je dobio Nobelovu nagradu kao priznanje za rad na holografiji (1971), Denis Gabor, naučnik koji je obogatio i umetnost, dobio je svoj portret načinjen pulsnim laserom, kao simbol primljene nagrade za veliki doprinos nauci.

Tako je postignuto nešto što do tad nije bilo viđeno $u$ umetnosti. Postoji i „povratna sprega“ - i umetnici unapređuju tehnologiju i opremu za holografiju. Projekti koji se baziraju na holografiji zahtevaju dodatne angažmane naučnika radi poboljšanja kvaliteta i mogućnosti postojećih sredstava.

Polja umetničke reprezentacije i kreativnosti su velika, što potvrđuje i slučaj holografije. 
Bojan M. Tomić

PROBLEMS OF THE HISTORY OF HOLOGRAPHY:

PREHISTORIC, METHODOLOGICAL AND SOCIAL

\section{Summary}

The Paper treats holography in a heuristic way. Also, methodology of historic research has been practiced through examples. Focus is on epistemological and historical aspects of the discovery, as well as on ways that can bring to it. History of holography has been shown in two parts. First part presents the problem of prehistory, which is the most prominent in the Paper. Possible patterns of prehistory are shown thereby. Second part is a presentation of the history of development of holography with the stress on early period (from 1947 to 1971), inside which, an outline of the work of the well-known representative Denis Gabor has been given. Discourse has been appended with applications, and a basic presentation of the influence of holography on art has been shown. 